\title{
Regional Policy on Socio-Cultural Adaptation of Migrant Workers in the Volga Region (Based on the Material of Samara Region)
}

\author{
Lyailya G. Khusnutdinova1 \\ Khanif S. Vildanov ${ }^{1}$ \\ Ludmila M. Andreeva ${ }^{1}$ \\ Rosa Kh. llyasova ${ }^{1}$ \\ Ildar M. Gabdrafikov² \\ 1 Ufa state University of Economics and Service \\ 2Ufa Scientific Center of RAS \\ E-mail: radogost2000@mail.ru
}

\section{Doi:10.5901/mjss.2015.v6n3s4p223}

\begin{abstract}
Samara region is one of the regions with high migration activity. For six years (2007-2012) by territorial body of the FMS of Russia in Samara region on the migratory account about 1 million 300 thousand foreign citizens and stateless persons, the vast majority of whom are members of the Caucasian and Central Asian ethnic groups was delivered. (Muxametshina, 2013, p. 38). The Samara region ranks fourth place in population among the regions of the Volga Federal district (more than 3.3 million people) and the twelfth largest in Russia. This region is unique in the variety of ethnic groups, cultures, languages, it can compete by the number of represented nations with Moscow, Tyumen region (Barysheva, 2007; Karabulatova, Sayfulina \& Ahmetova, 2013 \& Karabulatova, Koyshe \& Gultyaev, 2003). The purpose of this article is to review the role of public institutions in socio-cultural adaptation of migrants in the Samara region, in connection with which the authors solve the following tasks: provide a description of the social institutions participating in socio-cultural adaptation of migrant workers; determine the specifics of the migration processes and migration flows in the Samara region; substantiate the specificity of socio-cultural adaptation of migrant workers; conduct a comparative analysis of adaptation measures in the Samara region with other regions of Russia, near and far abroad.
\end{abstract}

Keywords: migration, migrant workers, adaptation, social culture, institutional settings.

\section{Introduction}

The desire of migrants to settle in the territory of the Samara region is caused due to climatic conditions and socioeconomic situation of the region: developed infrastructure, availability of land, relatively low population density and etc. According to the Russian Census 2010 in the region live about 140 ethos's and ethnic groups (Lyamin, 2014). Numerically in the Samara region dominates Russian - 2.6 million people which accounts for $85.6 \%$ of the total population. Second place in population in the area is occupied by the Tatars, their numbers is 126.1 thousand or $4.1 \%$ of the total population. In addition, in the Samara region is compact or dispersed are living a significant group of Chuvash, Mordovians, Ukrainians, Armenians, Kazakhs, etc., in the combination of components of $10.3 \%$ of the population (Results of the Russian Census, 2010). For the 12 months of 2013 on the territory of the Samara region was registered 272088 foreign citizens (Main indicators of the FMS of Russia in Samara region in 2013). For five months of 2014 for migration purposes are staged more than 100 thousand foreign citizens (In the Samara region the work on the legalization of labor migrants is conducted, ttt-grajdanin.ru/novosti-samarskoj-oblasti/v-samarskoj-oblasti-vedetsya-rabota-po-legalizaciitrudovyx-migrantov). Come foreign citizens mostly from countries of the Commonwealth of Independent States: the Republic of Uzbekistan (36\% of the number of arrivals from neighboring countries), the Republic of Tajikistan (18\%), the Republic of Armenia (11\%), Kazakhstan (10,8 \%) are arriving. The migration growth is increasing in the Samara region also due to the population exchange with distant foreign countries, which in 2012 amounted to 382 people (in 2010 - 48 people). Due to the domestic (inter-regional) movement of migrants a negative migration balance is formed (- 488 people.). (The general results of the migration on the constituent members of the Volga Federal district, 2013, 6). 
The vast majority of migrants are settling in urban areas ( $82 \%$ of the migration growth of the region) that corresponded to the level of urbanization of the region. The greatest population growth was observed in 2012 in city districts: Samara - 5,2 thousand, Kinel - 0,4 thousand, Chapaevsk - 0,3 thousand people and Pokhvistnevo - 0.2 thousand people. In the region, much is being done on the integration of migrants into the local community, as one of the priority directions of realization of the state national policy in the Samara region is the creation of favorable conditions for socio-cultural adaptation of migrants.

Russia is a state that is actively receiving migrants along with the USA, Germany, France, Canada and other major immigration countries (Lee \& Rutina, 2009). In big cities and different regions of Russia, high population growth rates with a variety of cultural characteristics, in various degrees different from the host, generate a number of serious social problems (Ryazantsev, et al 2014; Karabulatova, 2013 \& Karabulatova \& Polivara, 2013). Intensive growth of ethno phobia and migrant phobia, the distribution of these phobias on the indigenous peoples of Russia, the marginalization of the sociocultural environment of large cities are just some of the problems, associated with the regulation of migration processes (Zamaletdinov, Karabulatova, Yarmakeev \& Ermakova, 2014 \& Ryazantsev, Pismennaya, Karabulatova \& Akramov, 2014). As a result of these processes happens a powerful transformation of the identity of the migrant, which absorb a new culture, often marginalizing, losing its own individuality (Karabulatova, 2013, p. 753-754), however ethnopsycholinguistic norms of the host community turned to be not so effective in socio-cultural adaptation of migrants (Karabulatova \& Polivara, 2013, p. 834).

Today in Western civilization at the expense of the immigration inflow are solved some major problems, which are not solved by using of internal resources. Even to maintain the current standard of living it is necessary to replenish the population in connection with the depopulation of the "titular" ethnic groups; ensuring of the huge demand in low-skilled labor force; the feed of science intensive industries, the spheres of science and education of highly qualified personnel, necessary to maintain competitiveness. These problems are equally concerned Russia, but adequate mechanism for their solution still does not exist on the level of a coherent state program and procedural arrangements. To neutralize the negative impacts and enhance the positive effect, received from labor migration, the tools of public policare used. Mistakes in the choice of benchmarks of migration policies cause an undesirable reaction in the form of growth of illegal migration and subsequent social activity of returning migrants. In this area especially apparent is ineffectiveness of hard, legislative measures and the need for indirect, coordinating influences on the part of states and governments.

\section{Materials and Methods}

Social adaptation of migrants is largely a promising object of study of contemporary sociological theory. Being in its content and functions an integrative social science, sociology includes in the scope of the analysis all spheres of life of society on a broad interdisciplinary basis. However, believing in the spotlight of the man and his activity, sociology in a systematic and organic unity considers objective and subjective aspects of human activity. This very approach contributes to a fuller disclosure of regularities and mechanisms of migration processes in society, ultimately bringing together subject fields of philosophy, psychology, cultural studies and sociology.

The theoretical-methodological basis of this study also includes theoretical principles to the study of adaptive processes prevailing in social geography (Works of V. Anuchin, E. Alayev, Y. Saushkin), in adaptational psychology (L. Dikaya, V. Petroshevsky, N. Stepanov, A. Sukharev, G. Oberg, B. Hopson) and urbanology (Dridze, O. Janicki). The works of many scientists are devoted to the study of patterns, trends, types, shapes and directions of migration. The efforts of geographers (J.A. Zaionchkovskaya, V.M. Moiseenko, V.I. Perevedentcev, N.V. Yuxneva \& others) aimed to identify patterns of interaction between nature and society, as reflected in historical trends of settlement and migration. The subject of study of historians and sociologists has recently become the problems of displacement. Their work has received national color, where migration is considered from the standpoint of the formation of ethnic enclaves (L.N. Gumilev, V. Starovoitova, Z. V. Sikevich). Research of economists (G. S. Vechkanov, R. A. Kostin, L. L. Rybakovsky, S. $V$. Ryazantsev and others) are linked with the formation of labor resources, urbanization processes, structure of the economy. The social consequences of forced migration are discussed in several studies on youth (Z. V. Sikevich, T. S. Sulimova, B. A. Ruchkin, V. I. Chuprov, M. V. Sava and others). Approaches to the creation of "migrationology" (M. B. Denisenko, V. A. Iontsev, B. S. Choreev) are significantly augmented in the new environment of the researchers of forced migration, migration policy, social work with migrants (J. E. Bulatetskaya, V. P. Moshnyaga, V. A. Tishkov, A. Khokhlov, T. N. Yudina and other). Of a known interest are estimates of foreign experts on ethnic relations in the former Soviet Union (P. Goldman, J. Lagshdus, V. Zaslavsky and others).

The empirical base of the study was the results of sociological research, conducted by the authors on the basis of "National culture" of Ufa state University of Economics and service. In the study, conducted in 2010-2014, for a total were 
interviewed about 480 respondents. The sample of respondents was carried out in two stages: 1) selection of respondents by place of residence; 2) selection of respondents by gender, age, nationality, education and duration of stay on the territory of the region. To poll two types of settlement of forced migrants are selected: a dispersed and compact. The sampling bases were the data of Migration service of the Russian Federation on the number, age composition, place of origin and resettlement of forced migrants, as well as the data of Russian State Statistics Committe on the demographic composition of the population.

Simultaneously with the migrants were interviewed different groups of the local population. The obtained results were subjected to analytical description, correlation analysis, along with the methods of descriptive statistics.

As it is known, any activity always involves three aspects: motivation, purposeful and executive (Romm, 2002). Purposeful activity is always associated with social (including adaptive) needs of the individual. Having a goal that is associated with the necessity to meet the needs, the individual finds himself in a situation of choice. The implementation of the objectives of adaptive activity involves, therefore, a series of procedures:

1) the realization of adaptive needs that require satisfaction;

2) awareness of ways of it satisfaction;

3) finding the means of satisfying the needs;

4) the implementation of the activity (manifested in adaptive behavior as the response of adaptants on changes in the social environment), designed to meet adaptive need;

5) the consequence - the interpretation of the achieved results from the point of view of their compliance with the perfect original goals and individual needs.

Each of the stages that precede direct action, and it requires the satisfaction of the need for information, without which appropriate activities are fundamentally impossible.

\section{Results}

The success of social adaptation of migrants depends on several internal and external factors. Internal refers to the degree of mainstreaming the needs of migrants in positive social relationships, self-actualization and self-realization in work. External - the degree of acceptance of migrants by the host society and its ability to provide the necessary in the process of adapting of the identity of the migrant to new conditions of life, support and assistance. Adaptive activity is two - sided activity. Subject and spiritually influencing the social environment, person in the process of adaptation in this new adaptive environment converts himself through parallel fixture of own worldview and inner peace to the initiated by external changes. This is an active subjective nature of social adaptation of personality in the process of material and spiritual life.

In the region one of the priority directions of realization of the state national policy in the Samara region is the creation of favorable conditions for socio-cultural adaptation of migrants. This is the development and implementation of special programs, related to the integration and adaptation of arriving to Samara region foreigners. It is policy of the region, which is doing everything to strengthen the national unity of Russia and preserve the ethnic and cultural identity of the peoples of the Samara region. Thus, since 1994 in the region realized the regional target programs "Revival", "Different, but not wrong - peace through culture", "the Development of civil society" and others were realized. In December 2013 the Decree of the Government of the Samara region No. 803 "On approval of the State program of the Samara region "strengthening the unity of the Russian nation and ethno-cultural development of the peoples of the Samara region (2014 - 2020)" was signed. The State programme is aimed at strengthening the unity of the multinational people of the Russian Federation (the Russian nation) on the territory of Samara region."...In recent years in the Samara region on the background of increasing migration flows the changing of ethnic structure of the population, the rise in extremist movements and migrant phobia among the youth, ethnic and religious intolerance are also observed (v. Cuxie Avrali of Elkhovskiy district, v. Krotovka of kinel-cherkass district, v. studentsi of Khvorostyanski district).

The key problems in the area of the state of interethnic relations in the Samara region are: weak Russian civil identity with the increasing importance of ethnic and religious identity; ethno-political and religious-political radicalism and extremism; increase of the number of external labor migrants and their low socio-cultural adaptation to the host community; insufficient coordination of resources in order to achieve the harmonization of interethnic relations, the strengthening of civil unity of the multinational people of the Russian Federation (the Russian nation). In recent years in the region has been observed the intensification of ethnic and cultural life that is manifested in the creation and registration of new national-cultural associations. In 2012, in the Samara region were created 18 local and 4 regional public Association, including 16 local and 3 regional national-cultural autonomies. In 2013, for the first time in the Samara region were established regional and local national-cultural autonomy of the Yezidis, Tajiks, Germans, Gypsies. Often the 
emergence of new ethno-cultural associations and the intensification of social activities within one ethnic community lead to tensions between the leaders of these organizations. Reasons are in ambitious manifestations of leaders and also in the desire to receive preferential treatment from the state. In order to avoid the occurrence of conflicts within one ethnic group, the defacing of resources, the existence of destructive trends in the communities themselves, it is necessary to consolidate the asset in each national community. The formation of a single strong asset in the national communities is in a joint responsibility of state authorities and national-cultural public associations in the Samara region (decree of the government of Samara region No. 803). This State program was supposed to be a mechanism for the coordination of the state national policy in the Samara region, to develop regional strategies of ethno-cultural development, support dialogue between state authorities and public organizations, national-cultural and religious organizations. In "the Comprehensive plan for the harmonization of interethnic relations in the Samara region" a special section, which includes activities on adaptation and integration of foreign migrants is dedicated. In the State program of the Samara region "Promotion of employment of the population of the Samara region for 2014-2020" is included the sub-programme of "Social adaptation and integration of migrants arriving in Samara region, for 2014-2016" (Annex 1). The aim of the Subprogramme is to establish an effective model of adaptation and integration of migrants into account of the priorities of socio-economic development of the Samara region. Objectives of the Subprogramme: improvement of organizational and legal mechanism of regulation of the process of resettlement of migrants on the territory of Samara region; implementation of measures for social adaptation of migrants; promoting the integration of migrants in the host society. Total financing of activities of Subprogramme at the expense of means of the regional budget is 159210,5 thousand rubles, including: in 2014 - 79 413,2 thousand rubles; 2015 - 46 the total amount of 205.8 thousand rubles; in 2016 - 33 591,4 thousand [Subprogramme of "Social adaptation and integration of migrants, the online source].

In June 2014, in the building of the government of the Samara region a press conference with the participation of Deputy head of the FMS of Russia in Samara region D. Akimov, Minister of socio-demographic and family policy of the Samara region M. Antimonova and consultant of the Department of migration policy and integrated employment programmes of the Ministry of labour, employment and migration policy of the Samara region I. Danilochkina was held. It was about the organization of work with citizens of Ukraine who are arriving to the territory of the Samara region. In his speech, M. Antimonov said, "that on the line of work of the Ministry were registered 105 families (280 people) arrived to the Samara region from Ukraine. Of them, 140 people are of working age, 101 - children of preschool and school age and 24 of the pensioners. Most of them after the stabilization of the situation in the Republic hope to return to home. For refugees who have no relatives here a temporary stay on base of health centers, dispensaries, children's health centers will be prepared. The first place that will be open soon, will be designed for $100-200$ people. On the basis of employment centers with FMS were created additional centers for receiving documents from citizens coming from Ukraine. Also, based on labour requirements, in the Province are identified priority areas of settlement of Ukrainian citizens. This is the cities: Syzran, Novokuibyshevsk, Chapaevsk, Kinel, Volzhsky, Krasnoyarsk and Sergius areas. For those who wishes to provide the refugees with financial and humanitarian assistance special Fund was created" [In the Samara an activity is carried out...., Internet source]. In 2008 in the city of Samara was published the guide "migrant Communities in the Samara region: ethnic and religious features" for the public, municipal officials and employees of law enforcement agencies. Here on the basis of attracted extensive picture of the ethnic and religious characteristics of migrants from CIS countries and far abroad, with recommendations on inter-ethnic business etiquette and cultural norms are provided. In June 2008, in Samara was established LLC "Volga interregional multi-function center for support of migrants". The centre provided assistance to foreign citizens and stateless persons, employers and their representatives in obtaining work permits, temporary residence permits and residence permits, as well as the migration registration at the place of residence, assisted the employers in obtaining permits for attracting foreign labor force, conducted medical examination with the issuance of documents required for submission to the FMS of Russia, helped foreign citizens and stateless persons in employment, provided expert legal advice, contributed to the study of legal, language, traditional culture of the Russian Federation. However, the support Center of migrants was not able to work in full, and in the autumn of 2009 was actually preserved. Later, in December 2012 in Samara on zavodskaya highway the hotel of economy class "Second capital", created specifically for migrant workers, began its activities (450 rooms). Daily payment for accommodation starts from 150 rubles. The hotel has minimum necessary for life: rooms (some can accommodate up to 10 people), showers, a cafe with affordable prices, as well as a private kitchen and a game room. All migrants can rent a room with a passport of their country. The migration registration can also be done in the hotel, from where all the data is sent to the regional office of the FMS (In Samara was opened the hotel for immigrants. http:// www.gr.ru/2012/12/27/reg-pfo/migrantanans.html).

In the Samara region there are currently 8 centers for training and testing of foreign citizens in the Russian language organized with: Samara state University (SSU), "the learning Center for foreign citizens", Togliatti state 
University (TSU) "communication Centre", Tolyatti branch of the Russian Academy of national economy under the President of the Russian Federation, Volga state socially-humanitarian Academy (the humanitarian Academy), Samara humanitarian Academy (2 centers), Samara state economic University, NEE FVE "Vershina".

To the creation of favourable conditions for ethno-cultural development of the peoples of the Samara region, preservation of cultures, languages, traditions and customs contributes, established in 2001 in Samara "the House of friendship of peoples." With its support annually mass ethno-cultural events are taking place - Kazakh holidays "KamalAit" and "Navruz", Korean "Solal", Armenian "Terendez", etc. Since 2008, in the House of friendship of peoples were held a free consultation on migration issues for migrant workers and stateless persons, where they were provided with information on legal acts of the Russian legislation, adaptive courses "School migrant" were also held, seminars on "What is necessary to know about local customs and traditions for the foreigner", where the representatives of the UFMS of the Samara region, SI MIA of RF in Samara region are coming out, a variety of manuals and brochures for migrants are produced,- says N.P. Osipova, the head of national and religious policy of the Department of monitoring of public opinion (Osipova, 2013, p. 9).

Important role in the process of adaptation of migrants in a new place plays also social institutions. These include a variety of community organizations and first of all - national-cultural associations. Representing the interests of different ethnic groups, national-cultural associations carry out legal right of the peoples on self-regulation, regulate within ethnic processes, on the one hand, and also perform a very important function of "intermediary" in the dialogue between the state and ethnic communities on the other, contributing to the satisfaction of social needs.

Today on the territory of Samara region are registered more than 100 national-cultural public associations (LLC "League of Azerbaijanis of Samara region", Kirghiz organization "Manas-Ata", Tajik "Payvand-Unity", "the Uzbek community", etc.), also including 43 national-cultural autonomies of local, regional and Federal significance. In 2007, was registered with the Federal national cultural autonomy of Russian Kazakhs with center in Samara.

The purpose of the associations is the growth of national consciousness of the peoples of the Samara region, the revival and development of their national cultures. At the present time in Samara approximately 17 Sunday schools (Azerbaijani, Armenian, Georgian, Kyrgyz, etc.) are created and operate. The majority of national-cultural associations have its own publication. In the region with different frequency are published the following newspapers: the German "Volga-kurier", Ukrainian "Promin", Turkic "Azan", Kazakh "Ak zhol" Azerbaijan "Ochag", Kirghiz "Enee til" etc. Their target audience - labour migrants, the authorities, total circulation of ethnic newspapers is about 15 thousand copies.

In September 2014 in the village Zubchaninovka took place the opening of the Counseling center on the issues of the Gypsies population. However, a large group of Gypsies are not included in the social and cultural life of the Samara region, they remain in isolation; there are problems with the education of Gypsy children. Moreover, they are in need of help and support for more active involvement in the modern life of Russia. To this aim, the Administration of the Governor of the Samara region in the framework of implementation of the state program of the Samara region "strengthening the unity of the Russian nation and ethno-cultural development of the peoples of the Samara region (2014 - 2020)" (decree of the Government of the Samara region from 24.12.2013 No. 803) was supported by the project of opening a counseling center on the issues of the Gypsy population in the Samara region. Advising on the registration of the missing documents, information about possible social support, employment and starting one's own business, legal advocacy issues that can be discussed and resolved. In the framework of this project will be resumed publication of the regional Gypsy newspaper (Discovery counseling center on the issues of the Gypsy population).

Help in social integration and adaptation of migrants in the local community carry out also religious institutions of the Samara region. "The proportion of migrants, who came to work independently and do not address to their countrymen, go to the mosque for financial help, for information. In mosques of Samara, Tolyatti, Syzran, other cities, in rural mosques such support is provided constantly. Regional Spiritual Board of Muslims of the Samara region cooperates with the national-cultural organizations representing the interests of "ethnic Muslims", so the mosques know their contact numbers, address of the House of peoples ' friendship. However, there is no any special adaptation-integration programs in the Regional Spiritual Board of Muslims of the Samara region. "Every month, every Friday, we consider the application of Muslims who ask for help. Requests are different, including the treatment of migrants who, for one reason or another were left without means of subsistence. And Muslims, as possible try to help them. Also in the mosque migrants can bathe and freshen up, "says Imam of Samara mosque I. H. Safin. - To the mosque go Muslims who come to work in Samara region. This is mainly migrants from Uzbekistan, Tajikistan, Kazakhstan, a small part of Turkmenistan".

In the context of migration processes the social adaptation acts as a special type of social process aimed to include in the public life the categories of people who were artificially removed from this life under the influence of some extraordinary factors. 


\section{Discussion}

The term adaptation (from lat. adaptatio - adaptation) as a scientific concept first appears in physiology in 2nd half of the XIX century by German physiologist G. Aubert and meant adapting the sensitivity of the organ of vision or hearing to the action of external stimuli. Currently, the adaptation is one of the most important interdisciplinary scientific concepts that have been widely and intensively analyzed in medico-biological, cybernetic and social sciences. In this article, we are interested in one of the most important types of adaptation - social adaptation, which we will consider in terms of social groups of forced migrants and local territorial community (Rybakovsky, 2003).

In several publications (V.V. Amelin, V.C. Belozerov, F.M. Borodkin, E. M. Vinogradov, Z.I. Kalugin, I.S. Karabulatova, L.V. Korel, R.A. Kostin, E.A. Melnik, S.A. Panarin, S.V. Ryazantsev et al.) the adaptation of migrants in different regions of Russia are highlighted.

Of particular interest for the development of sociological theories of adaptation of migrants are the works of L.V. Makarova, G.F. Morozova, L.L. Rybakovsky, N.V. Tarasova, V.D. Shapiro on theoretical modeling of migration behavior. Although in recent years, research on the problems of refugees and IDPs (internally displaced person) has become much more active, many questions remain insufficiently developed: the fundamental issues of methodological and conceptual issues associated with the disclosure of the nature of migration, identifying the causes, methods of measurement of its intensity and effectiveness still was not resolved.

\section{Conclusions}

Today Russia faces the problem of adaptation in a variety of social, cultural and ethnic categories of foreign workers, the number of which, as projected researchers, in the coming years will only increase. Especially it is necessary to develop theoretical tools of research, which clearly distinguish the sociological aspect of the problem and the role of spatial factors in the adaptation of migrants in the territories of sustainable migration growth.

The high level of xenophobia and a low level of tolerance of the population, corrupt power structures and the lack of clear federal and regional policies for socio-cultural integration of migrants make difficult the inclusion of migrants into Russian society on the model of multiculturalism, which many researchers indicate as the only possible in a democratic state and conforming to international trends. However, its framework of interaction between migrants and the host community also may have a conflicting character. But, this model implies the willingness of the majority of society to accept cultural differences and accordingly modify social behavior in society, and even its social structure.

\section{Aknowledgment}

Publication realized with the financial support of the Government of RHF and the Republic of Bashkortostan "Ural: history, economy, culture" research project number 14-11-02011 and research project № 14-11-02011 «The role of nationalcultural associations in the Volga region (the Republic of Bashkortostan, Tatarstan, Samara Region)"

\section{References}

Barysheva, Y.S. 2007. Socio-cultural adaptation of migrants in the modern metropolis: on example of Moscow.

In the Samara region the work on the legalization of labor migrants is taking place [Electronic resource]. - Access mode: http://tltgrajdanin.ru/novosti-samarskoj-oblasti/v-samarskoj-oblasti-vedetsya-rabota-po-legalizacii-trudovyx-migrantov/

In Samara was opened the hotel for immigrants. http:// www.gr.ru/2012/12/27/reg-pfo/migrant-anans.html.

A report on the results and main activities of the DFMS of the Samara region for 2013 and the planning period of 2014-2016. V.: Current archive of VFMS of Russia in Samara region.

Karabulatova, I.S. 2013. The problems of linguistic modeling of new Eurasian linguistic personality in multilinguistic and mental environment (by example of onomasphere). In the: Middle-East Journal of Scientific Research 17 (6), pp. 791-795.

Karabulatova, I.S. \& Polivara Z.V. 2013. Turkic and Slavs: bi-polylinguism in globalization and migrations (on an example of Tumen region) // Middle-East Journal of Scientific Research 17 (6): pp. 832-836.

Karabulatova, I.S., Koyche K. \& Gultyaev V.N. 2013. The Dialogue of Kazakh Steppe and Russian Forest: About the Character of Turkic-Speaking Linguistic Personality on the Territory of Russian-Kazakhstani Border-Zone // Middle-East Journal of Scientific Research 17 (7). pp. 853-858

Karabulatova, I.S., Sayfulina F.S. \& Ahmetova B.Z. 2013. Ethno-lingual aspect of modern functioning of Russian dialects in North Kazakhstan (on an example of Kostanai region). In the: World Applied Sciences Journal Issue 27 (Education, law, economics, language and communication). pp. 137-140.

Lee, J. \& Rutina N. 2009. Naturalizations in the United States: 2008. In the: Annual flow report. http://www.dhs.gov/xlibrary/assets/ 
statistics/publications/natz_fr_2008.pdf.

Lyamin, A.S. 2014. The experience of the implementation of ethno-cultural dialogue in the XXI century on the example of Samara region. Mukhametshina, N.S. 2013. The cultural integration of migrants: social, cultural and political aspects. In the: Problems of ethno-cultural interaction in the Ural-Volga region: history and modernity: a collection of articles of II international scientific conference, Samara, September 19-20, 2013, Samara : "the Samara humanitarian Academy". pp. 38.

The general results of the migration of the population by regions of the Volga Federal district. V.: Population migration in the Republic of Bashkortostan: a statistical compendium. In 2 parts 1. Edited by A. M. Ganiev, V. A. Vassiliev, R. Sh. Gataullin etc. Ufa: Bashkortostanstan, 2013. pp. 6.

Key performance indicators of the VFMS of Russia in Samara region for 2013. In.: Data of the current archive of the FMS of Russia in Samara region.

Osipova, N.P. The regional model of the state national policy as a factor of interethnic stability. In: Problems of ethno-cultural interaction in the Ural-Volga region: history and modernity : a collection of articles of II international scientific conference, Samara, September 19-20, 2013 Samara, "the humanitarian Academy", 2013. pp. 31.

The sub-programme "Social adaptation and integration of migrants arriving in Samara region, for 2014 - 2016. In: an application to the state program of the Samara region "Promotion of employment of the population of the Samara region for 2014-2020". The current archive of the Ministry of labour, employment and migration policy of the Samara region.

The decree of the Government of the Samara region from 24.12.2013, No. 803 "On approval of the State program of the Samara region "strengthening the unity of the Russian nation and ethno-cultural development of the peoples of the Samara region (2014-2020)" // the Current archive "House of friendship of peoples", Samara region.

Ryazantsev, S.V., Pismennaya E.E., Karabulatova I.S. \& Charif Y. Akramov. 2014. Transformation of sexual and matrimonial behavior of Tajik labor migrants in Russia. In the: Asian Social Science. Vol 10, No.20. pp. 174-183.

Romm, M.V. 2002. Adaptation of the individual in society: Theoretical and methodological aspect. - Novosibirsk: Nauka. Siberian publishing firm of RAS. pp. 173.

Rybakovsky, L.L. 2003. Social adaptation of migrants. In: Sociological encyclopedia. In 2 vols.) Vol. 1. M. pp. 116.

Zamaletdinov, R.R., Karabulatova I.S., Yarmakeev I.E. \& Ermakova E.N. 2014. Linguo-propaedeutics of ethnic conflicts as a basis for Stability in complex polyethnic regions. In the: Asian Social Science. Vol 10, No.20. pp. 164-173. 
ISSN 2039-2117 (online) ISSN 2039-9340 (print)
Mediterranean Journal of Social Sciences MCSER Publishing, Rome-Italy
Vol 6 No 3 S4 May 2015 